\title{
Lymphocintilographic evaluation of lymphatic circulation in victims of circuferential degloving injuries of the lower limbs
}

\section{Avaliação linfocintilográfica da circulação linfática em pacientes vítimas de desenluvamentos circunferenciais dos membros inferiores}

\author{
Daniel Francisco Mello, TCBC-SP1 iD; Jose Cesar Assef, TCBC-SP2; Americo Helene-JR¹.
}

\begin{abstract}
A B S T R A C T
Introduction: secondary forms of lymphedema may occur as consequence of tumors, surgeries, radiotherapy, trauma and infections. Degloving injuries are severe and infrequent forms of trauma, with avulsion at the level of muscular fascia, and consequent injury of the lymphatic system. Objective: to evaluate the alterations in lymphatic circulation in patients being victims of circumferential degloving injuries in the lower limbs, using lymphoscintigraphic. Patients and Methods: retrospective analysis of the cases treated in the period from 2010 to 2016. Segmental, circumferential and unilateral injuries with involvement of the lower limbs were included. Lymphoscintigraphy was performed after a minimum interval of 12 months after the end of treatment. The non-injured lower limb was used as control. The Kleinhans Semiquantitative Index (KSI) was used for the semiquantitative evaluation of the lymphoscintigraphic findings. Results: eighteen patients were evaluated, six of whom were female and 12 were male. The mean age was 28.11 years. The average vertical extension of the circumferential traumatized segment was $29.33 \mathrm{~cm}$. The injured area presented variations of 5 to $15 \%$ of the body surface, with an average of $8.95 \%$. Lymphoscintigraphy was performed after an average interval of 22.55 months. Alterations were observed on the traumatized limb (TL) in 13 patients. All control limbs (CL) were normal. The mean KSI observed in TL was 8.32, while in $C L$, the average value was 0.58 ( $p<0.001$ ). Conclusion: patients with circumferential degloving injuries in the lower limbs present compromised lymphatic circulation and high probability to develop lymphedema.
\end{abstract}

Keywords: Lymphedema. Soft Tissue Injuries. Skin. Fascia. Radionuclide Imaging.

\section{INTRODUCTION}

T he lymphatic system is a complex network, made up of capillaries and lymphatic vessels, lymph nodes, and lymphatic organs, which are vitally important for the maintenance of liquid homeostasis and for immunological aspects'.

Lymphedema can be understood as a manifestation of the insufficiency of the lymphatic system due to an alteration in circulation, that is, a reduction in transport of primary or secondary origin. It should not be understood only as a simple local edema process, but as a complex and systemic disease ${ }^{2,3}$.

Secondary forms of lymphedema, also called obstructive, are the most frequent, in more than $95 \%$ of cases $^{4,5}$. There are clinical signs, which are usually more accentuated the greater the degree of stasis and the longer the duration of the process.

The etiologies normally associated with this type of injury are $\mathrm{a}^{6,7}$ :

- Malignant neoplasms, as well as related treatments

- Infections and parasitic infestations

- Surgical trauma

- Radiotherapy

- Trauma

So far, there are no factors that allow predicting the occurrence of lymphedema after trauma, operations,

1 - Irmandade da Santa Casa de Misericórdia de São Paulo, Serviço de Cirurgia Plástica - São Paulo - SP - Brasil 2 - Irmandade da Santa Casa de Misericórdia de São Paulo, Serviço de Emergência - São Paulo - SP - Brasil 
or procedures, and genetic predispositions associated with environmental factors may play a role $3,8,9$.

There is scarce literature related to cases of post-traumatic lymphedema, and occurrences related to extensive injuries and deep burns can be found, with or without skin grafts, including prolonged latent periods ${ }^{10-16}$.

Some authors have described that posttraumatic lymphedema can occur months or even years after trauma to the lower limbs. They also highlighted that there are still significant limitations in analyzing the evolution of the lymphatic system in the healing process. They considered that there may be recanalization or even regeneration in scarring areas, including partial thickness skin grafts $15,17,18$.

Degloving injuries are uncommon skin and soft tissue traumas, characterized by avulsions of the skin and subcutaneous tissue from the plane of the muscle fascia, involving injury to the fasciocutaneous and musculocutaneous perforating vessels. They result from the application of sudden and high intensity forces with tangential vectors, promoting compression, stretching, torsion, and friction of the structures. Most injuries present as a continuity solution of variable size, with exposure of the fascia and muscles, being called open, typical, or anatomical degloving ${ }^{19,20}$.

In our service, we observed that, in cases with circumferential involvement, especially when there is greater vertical extension, postoperative edema of the distal segment was more significant and prolonged. This study aims to evaluate the sequelae and alterations of the lymphatic drainage in victims of circumferential degloving injuries of the lower limbs, based on lymphoscintigraphic analysis.

\section{METHODS}

We conducted a retrospective analysis of medical and photographic records of degloving injuries cases affecting the lower limbs, treated in the period from 2010 to 2016.

We included cases with exclusive trauma to the lower limbs, with segmental, circumferential, and unilateral involvement, who underwent debridement of traumatized tissues, subsequent wound preparation, and partial skin grafting.
The exclusion criteria were:

- Bilateral lower limb trauma;

- Associated vascular trauma;

- Amputation of lower limb segment;

- Previous edema of systemic etiology heart, renal, thyroid, or liver failure;

- Personal history of vascular surgeries in the lower limbs;

- Personal history of thromboembolic events or diagnosis of post-thrombotic syndrome; and

- Morbid obesity.

We analyzed sex, age, date of trauma, interval until the lymphoscintigraphy examination, affected body surface (ABS) by degloving injury (in \%, using the Lund and Browder table), and vertical extension of the traumatized circumferential segment (in $\mathrm{cm}$ ).

Regarding the type of skin graft used, all cases underwent a conventional hin split-thickness skin graft, removed with a Blair knife, with small random perforations for drainage. Expansion of the grafts by means of a reticular apparatus (mesh graft) was not performed.

Lymphoscintigraphy (LFCG) was performed after a minimum interval of 12 months after the initial surgical treatment (skin grafts in the raw areas). We used the non-traumatized lower limb as a control.

To assess the lymphoscintigraphic findings, we used the Kleinhans Semiquantitative Index - KSI. We assessed the patterns of distribution, flow and path of lymphatic vessels, time to identify inguinal lymph nodes, and appearance, as well as the presence of collateralization, dermal reflux (DR), and the existence of a popliteal lymph node.

The Kleinhans Semiquantitative Index ranges from 0 to 45, values less than 10 being considered normal. The maximum time for lymph nodes to appear is $200 \mathrm{~min}$, with a score of 8 . The absence of uptake will receive a score of 9 . For statistical analysis of these results, we used the Wilcoxon and Mann-Whitney tests.

This study was approved by the Ethics in Research Committee of the Irmandade da Santa Casa de Misericórdia of São Paulo, being registered under number 
(CAAE) 54209416.4.0000.5479 and opinion 1.569,384. All patients signed an informed consent form.

\section{RESULTS}

In the period from 2010 to 2016, 75 victims of degloving injuries with involvement of the lower limbs were treated, and of these, 18 met the inclusion criteria. In this group, 12 (66.7\%) were males and six (33.3\%) females. All patients had been run over by motor vehicles. The mean age observed was 28.11 years (12-48).

The average affected body surface was $8.95 \%$ (5-15\%). The mean vertical extension of the traumatized segment was $29.33 \mathrm{~cm}(15-50 \mathrm{~cm})$ (Figures 1 to 6$)$.

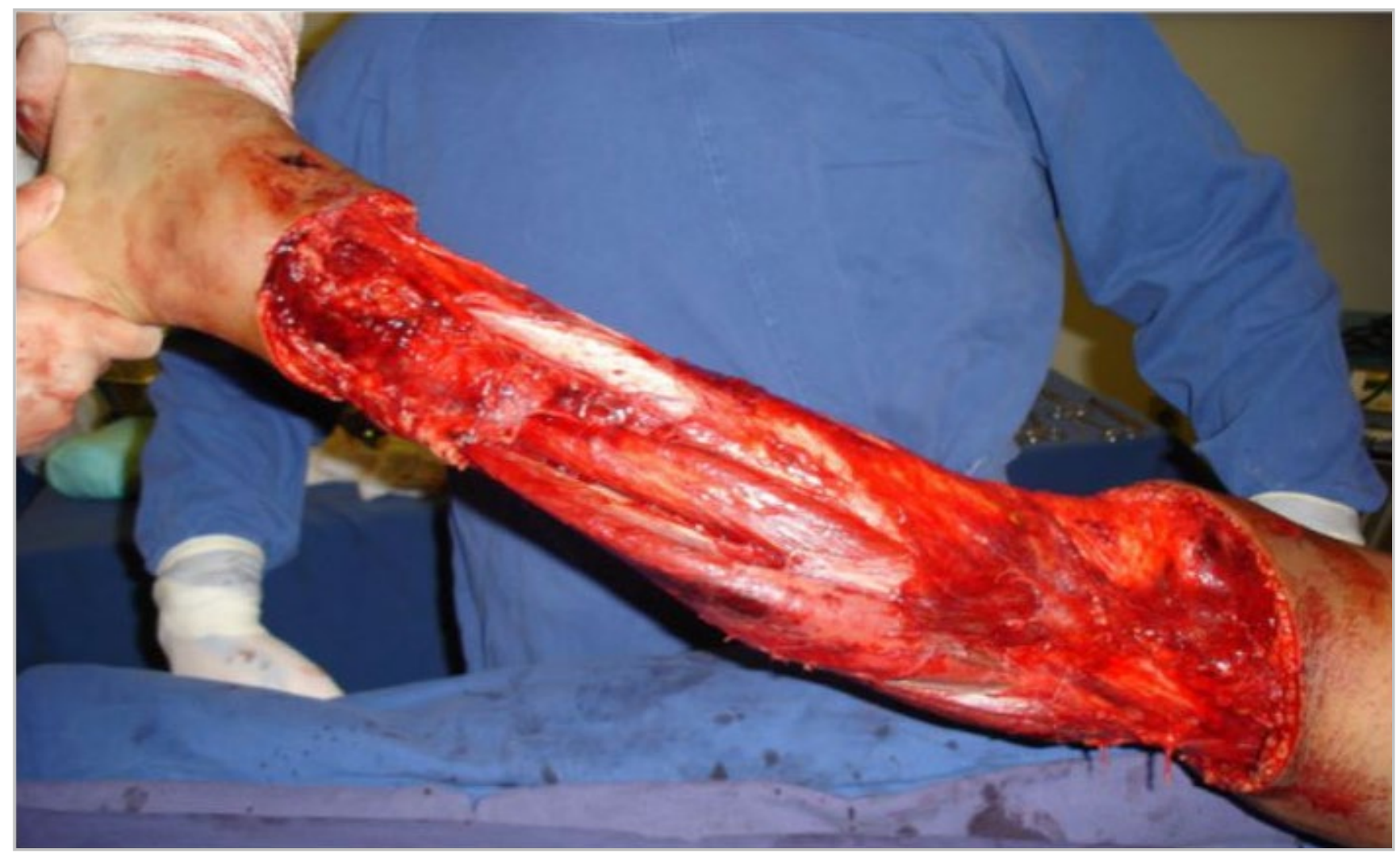

Figure 1. Case 1 - Circumferential degloving injury in the left leg, $9 \%$ ABS, vertical extension of approximately $35 \mathrm{~cm}$; admission.

As for the affected side, the left corresponded to $55.6 \%$ of the cases (10), and the right, to the other eight patients. The time elapsed between treatment and lymphoscintigraphy was on average 22.55 months (1331).

Regarding the occurrence of clinical manifestations in the traumatized limb (TL), these were present in 14 cases $(77.7 \%)$, only edema being evidenced, observed from 12 to 18 months (according to reports and subjective assessment of patients). No local infection or thromboembolic events were observed, either in the TL or in the control limb $(\mathrm{CL})$.

As for the classification of the International Society of Lymphology, we observed four Grade 0 cases, six Grade 1, and eight Grade 2 cases. There were no Grade 3 cases.

All patients underwent the LFCG exam within the established protocol and without complications. Changes in the TL examination were present in 13 cases (72.22\%) and absent in five. The LFCG exam was normal in all CLs.

The mean KSI observed in the TL was 8.32 (0.320.75), and we observed indexes $>10$ in nine patients. In CL the mean value was $0.58(0.15-0.75)$ (Table 1 and Figures 7 and 8).

We observed five normal exams in the traumatized limbs, of which three did not present clinical manifestations. The other two had edema. In the group 
of patients who had altered lymphoscintigraphic exams (13), only one had no clinical manifestation. Table 2 shows the comparison of patients with normal and altered KSI exams.

Table 1. Comparison between $T L$ and CL lymphoscintigraphic exams.

\begin{tabular}{lccc}
\hline & KSI TL & KSI CL & p-value \\
\hline Average & 8.32 & 0.58 & 0.001 \\
Median & 8.62 & 0.63 & \\
$95 \% \mathrm{Cl}$ & $5.07-11.56$ & $0.49-0.68$ & \\
\hline
\end{tabular}

Table 2. Comparison between normal and altered lymphoscintigraphic exams.

\begin{tabular}{lcc}
\hline & KSI - TL & KSI - CL \\
\hline Normal exam - 5 cases & 0.63 & 0.55 \\
Altered exam - 13 cases & 11.27 & 0.6 \\
\hline
\end{tabular}

Table 3 shows the comparative data of the KSI observed in TLs.

Table 3. Comparison between TL lymphoscintigraphic exams (KSI).

\begin{tabular}{lccc}
\hline & Normal & Altered & p-value \\
& 5 cases & 13 cases & \\
\hline Average & 0.63 & 11.27 & 0.001 \\
Median & 0.75 & 11.85 & \\
$95 \% \mathrm{Cl}$ & $0.27-0.98$ & $8.19-14.36$ & \\
\hline
\end{tabular}

Mann-Whitney Test.

As for the occurrence of TL fractures, there were 11 cases. Table 4 brings the data referring to the findings of the LFCG exam. There were no cases of fractures in the $\mathrm{CL}$.

Table 4. Relationship between LFCG results and fractures in the traumatized limb (TL).

\begin{tabular}{lcc}
\hline & Normal LFCG & Altered LFCG \\
\hline Fracture - Present & 4 & 7 \\
Fracture - Absent & 1 & 6 \\
\hline
\end{tabular}

\section{DISCUSSION}

There has been an increase in the incidence of lymphedema, but unfortunately there is limited attention by the public and supplementary health systems, even in developed countries ${ }^{21-23}$.

Lymphedema is an inhibiting factor for healing. After trauma, there is the formation and opening of collateral lymphatic vessels, as well as the opening of connections between the superficial and deep systems ${ }^{10.15,24,25}$.

Trauma rarely presents itself as an etiology for lymphedema, and there are few related publications. Lesser lesions, even if repetitive, present effective healing and vascular and lymphatic repair. For more extensive lesions, observations in the literature are inconsistent ${ }^{26,}$ 27

Figure 2. Case 1 - Circumferential degloving injury in the left leg, $9 \%$ $A B S$, vertical extension of approximately $35 \mathrm{~cm} ; 26$ months after partial skin graft. 


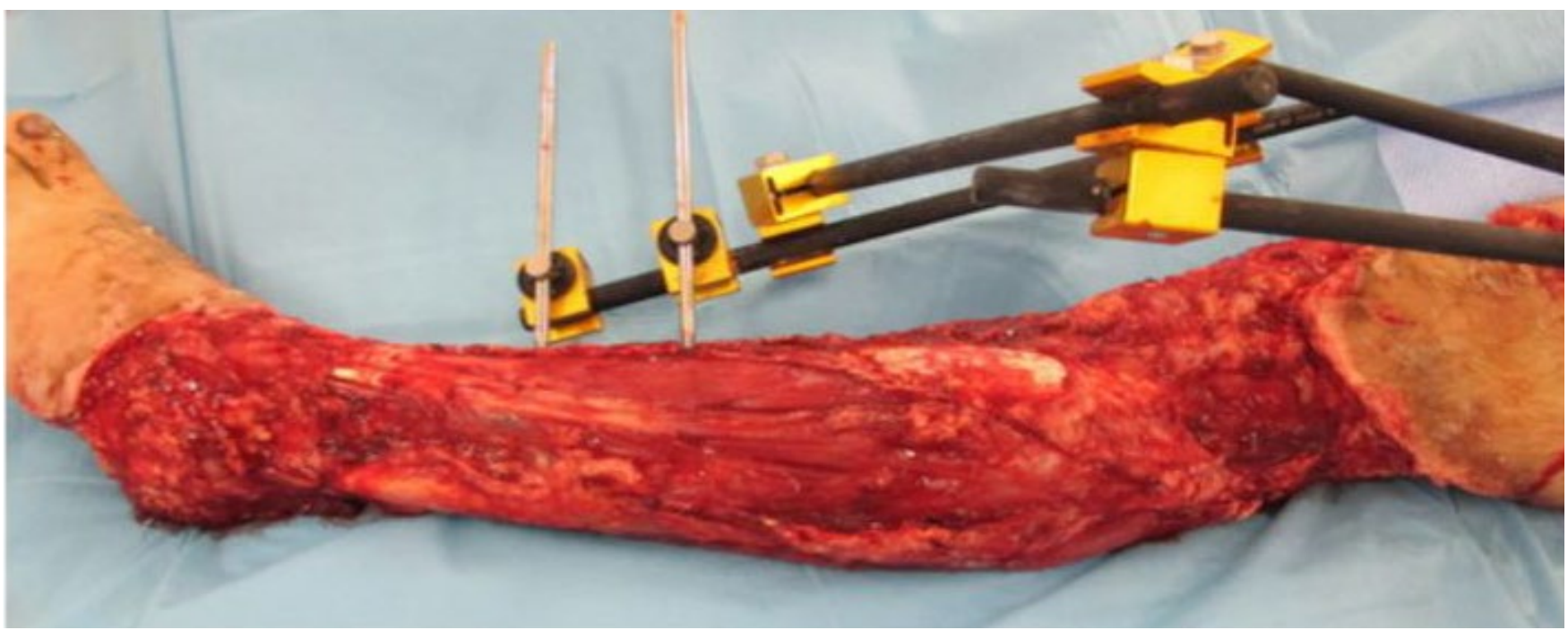

Figure 3. Case 2 - Circumferential degloving injury in left foot, ankle, leg, and left knee, $10 \%$ ABS, vertical extension of approximately $50 \mathrm{~cm}$; admission.

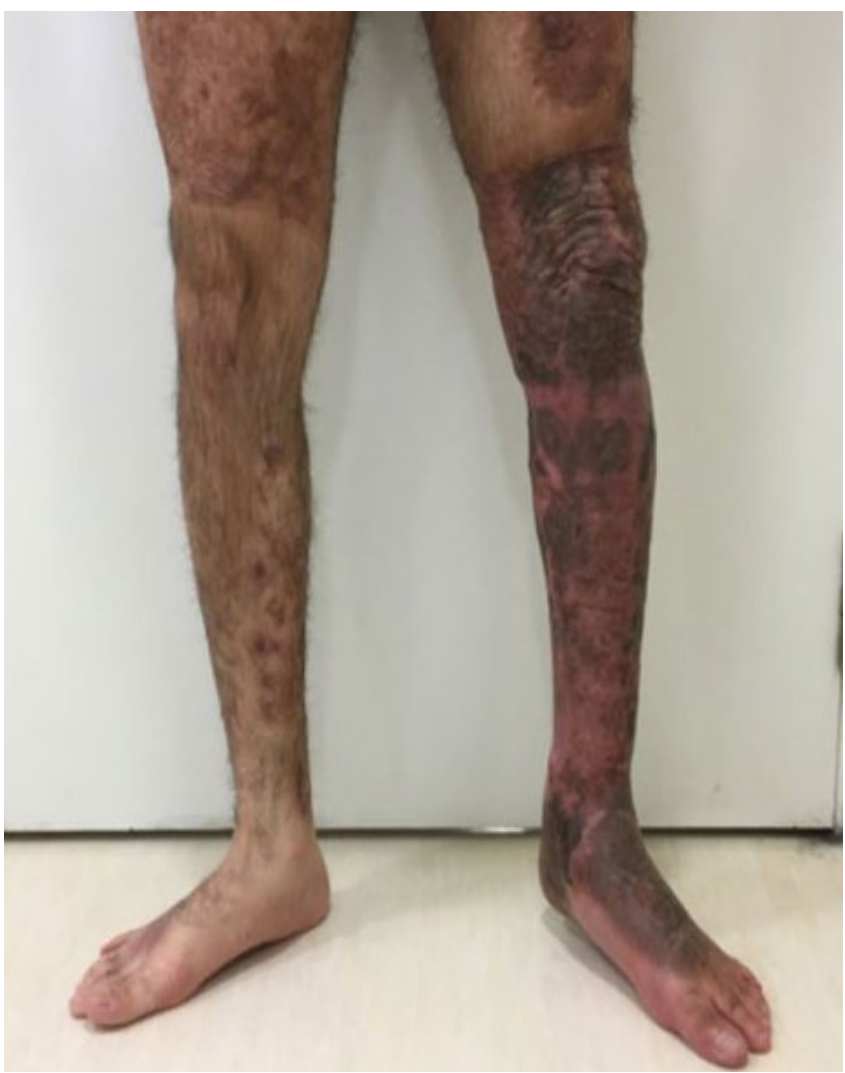

Figure 4. Case 2 - Circumferential degloving injury in left foot, ankle, leg and left knee, $10 \%$ ABS, vertical extension of approximately $50 \mathrm{~cm}$; 20 months after partial skin graft.

As mentioned, the occurrence of post-traumatic lymphedema is a rare and even unpredictable occurrence. The existing observations come from case reports, mostly or at most from small series. One must also consider the limitations for analyzes based on these publications, given the different etiologies involved. Cases have been reported after a few months to a few years. One could question whether there was an evaluation only from more evident edema cases, with a possible existence of undiagnosed cases in earlier periods.

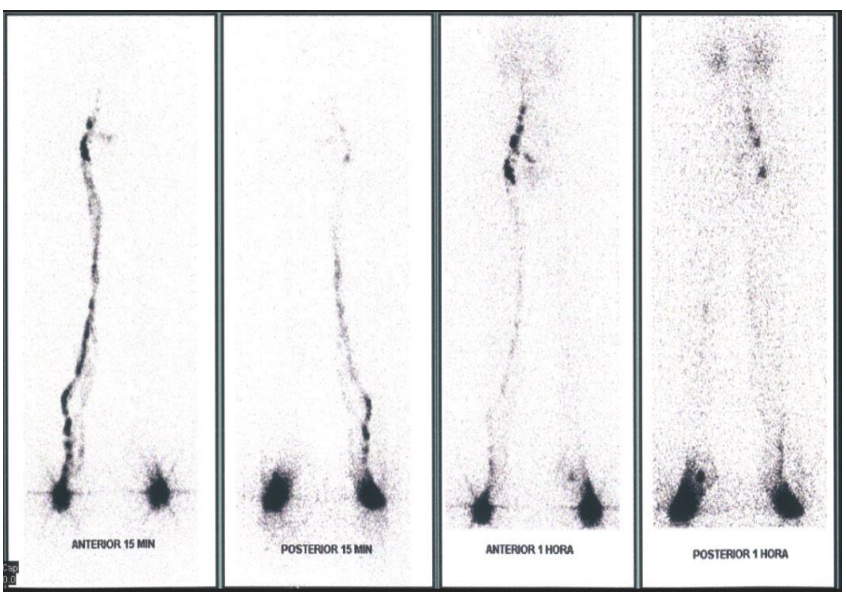

Figure 5. Lymphoscintigraphy of case 1.

- Time to appearance of inguinal lymph nodes: Right $=8 \mathrm{~min} /$ Left $=30 \mathrm{~min}$.

- Left = Marked flow reduction, mild DR, reduced lymphatic vessels, reduced inguinal lymph nodes.

- $\quad$ KSI Right $=0.6 /$ Left $=20.75$

LFCG is the most used test to assess the lymphatic system, as well as for suspected lymphedema, still considered the standard test. It is a non-invasive procedure and is associated with minimal discomfort. Its disadvantages are the use of ionizing radiation and limited anatomical resolution ${ }^{28-30}$. 


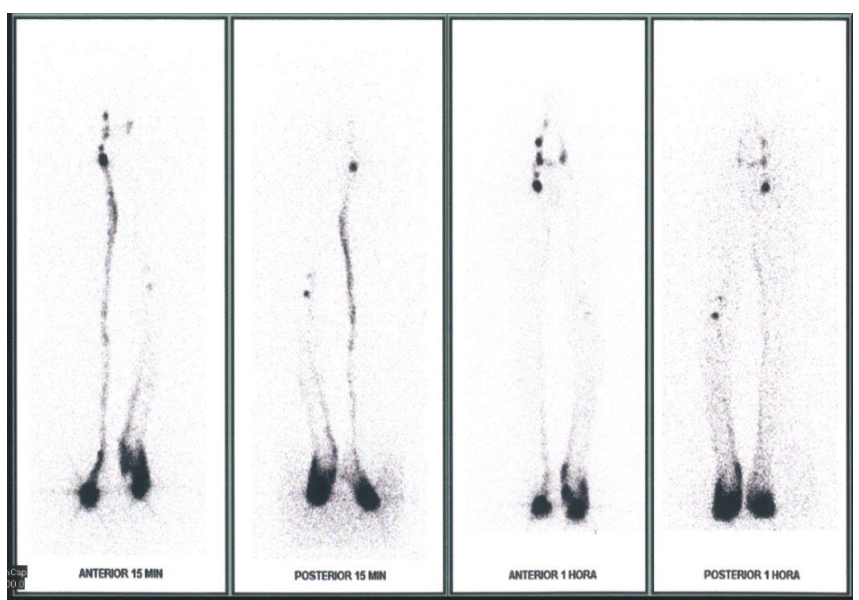

Figure 6. Lymphoscintigraphy of case 2.

- $\quad$ Time to appearance of inguinal lymph nodes: Right $=4 \mathrm{~min} /$ Left $=13 \mathrm{~min}$.

- $\quad$ Left $=$ Marked flow reduction, mild $D R$, reduced vessels, reduced inguinal lymph nodes, popliteal lymph node present.

- $\quad$ KSI Right $=0.37$ / Left $=14.97$.

As for the LFCG findings, the presence of a popliteal lymph node is a sign of failure of lymphatic drainage through normal pathways. Dermal reflux is a sign of contrast extravasation due to hypertension in the proximal collectors, and contrast retention is a sign of overload and increased local hydrostatic pressure. Collateral circulation is also a pathological marker ${ }^{31}$. The Kleinhans's index has a sensitivity of $97.4 \%$ and a specificity of $90.3 \%$. It is considered reliable and is well associated with clinical conditions ${ }^{32,33}$.

As for the time to perform the LFCG, we did not find any reference to similar cases in the literature for comparison. We chose to establish a period of 12 months after the partial skin graft, believing that the edema related to the usual postoperative period would have already regressed.

We observed five normal LFCG exams in the $T L$, and three of these patients also did not present symptoms. In the other two cases, there was edema. We did not find infectious conditions or thromboembolic events. The possibility of the occurrence of clinical or LFCG alterations in a longer follow-up period is disputed.

We did not expect normal results in LFCG exams in TL. There are no similar cases in the literature that allow for comparisons. From an anatomical point of view, we can assume that there was a complete loss of conventional superficial lymphatic circulation pathways in the lower limbs secondary to circumferential and extensive degloving injury.
Although there are no specific studies in the literature, we believe that the fenestration of the skin layers used may mean extra damage to the residual dermis and greater difficulties for recanalization or maintenance of flow through the residual lymphatic vessels.

split-thickness skin grafting is an unfavorable factor for the neoformation of lymphatic vessels, although this is an impression of case reports or small series. The available results show the absence of vessels in the segment directly below the grafted skin layers, which is a significant problem in cases such as the ones in this series, as they are grafts of greater length.

As for the existence of TL fractures, there was no association with severity or alterations in LFCG. In the 11 cases with fractures, four had normal exams. LFCG displayed alterations in six of the seven cases without fractures.

In our cases, all treatments for fractures were successful, without the occurrence of instability, lack of consolidation, or pseudarthrosis. All patients had open fractures with the possibility of bone coverage despite the soft tissue injury (Gustillo Illa). More complex reconstructions with flaps (Gustillo Illb) were not necessary, nor were associated vascular lesions requiring repair (Gustillo IIIc).

Sapienza et al..$^{33}$ highlighted the identification of prominent lymphatic vessels or those with collaterals, as well as DR, in cases of edema after trauma or operations. The observation by Van Zanten et al. ${ }^{18}$ is that there can be recanalization or even regeneration in scar areas or after trauma. These authors evaluated 17 cases of patients with Gustillo Illb open fractures. Factors such as inflammation and hypoxia can also be limiting for the neoformation of lymphatic vessels ${ }^{34,35}$.

Lymphedema must be understood as a chronic, incurable, and slowly progressive disease, requiring lifelong treatment. The need for continuous care does not mean it cannot be effective or satisfactory ${ }^{2,3,36}$. In cases of treatment failures or difficulties, progressive skin changes, recurrent infections, progressive physical limitations, and psychosocial problems are observed ${ }^{2}$.

Considering the mechanism involved for the occurrence of degloving injuries, with transfer of significant amounts of energy after the contusion, in addition to the frequent association with fractures, we 
can assume limited lymphatic circulation regeneration after skin grafting, which in fact occurred in most of our cases.

Prevention is directly related to clinical followup and active investigation of cases, which should already be stratified as higher or lower risk for early lymphedema. Importantly, LFCG can demonstrate lymphatic alterations before the existence of clinical alterations ${ }^{9}$.

There is still no definition regarding the moment to start treatment of mild or subclinical cases, as well as the best moment for the indication in the case of physiological operations, in the latter case considering the potential prophylactic effect.

The number of early diagnoses should increase. While this does not occur, the identification of populations at higher risk, in need of intensive surveillance, is essential. Victims of lower limb degloving injury, especially circumferential injuries, are included in this group.

Due to the small number of cases that could meet the proposed inclusion criteria, in particular the occurrence of circumferential unilateral trauma with a preserved contralateral limb to allow comparison of the lymphoscintigraphic examination, we did not carry out a sample size calculation, nor other more elaborate statistical analyses.

Such a small group analysis is undoubtedly a significant limitation of the study. However, it demonstrates a high risk of complications and confirmation by an accessible complementary exam in more complex cases of this type of trauma to the lower limbs. These findings even led us to change the posttrauma follow-up routine in patients who suffered from degloving injuries in our service, which will allow for further analyzes and publications in the future.

\title{
R E S U M O
}

\begin{abstract}
Introdução: as formas secundárias de linfedema podem ocorrer em consequência de tumores, cirurgias, radioterapia, traumas e infecções. Os desenluvamentos são formas graves e infrequentes de trauma, sendo observada avulsão no plano da fáscia muscular, com consequente lesão do sistema linfático. Objetivo: avaliar as alterações na circulação linfática nos pacientes vítimas de desenluvamentos circunferenciais nos membros inferiores, a partir da análise linfocintilográfica. Pacientes e Métodos: análise retrospectiva dos casos atendidos no período de 2010 a 2016. Foram incluídos os casos com acometimento segmentar, circunferencial e unilateral em membros inferiores. A linfocintilografia foi realizada após um intervalo mínimo de 12 meses do término do tratamento. O membro inferior não traumatizado foi utilizado como controle. Para a avaliação semiquantitativa dos achados linfocintilográficos, utilizou-se o Índice de Kleinhans (ISQTK). Resultados: foram avaliados 18 pacientes, sendo seis do gênero feminino e 12 do masculino. A média de idade foi de 28,11 anos. A extensão vertical do segmento traumatizado circunferencial foi em média de $29,33 \mathrm{~cm}$. 0 segmento traumatizado apresentou variações de 5 a 15\% da superfície corporal, com média de 8,95\%. A linfocintilografia foi realizada após intervalo médio de 22,55 meses. Foram observadas alterações no exame linfocintilográfico do membro traumatizado (MT) em 13 pacientes. Todos os exames dos membros controle (MC) foram normais. O ISQTK médio observado no MT foi 8,32 (0,3-20,75). No MC o valor médio foi de 0,58 (0,15-0,75). Conclusão: os pacientes com desenluvamentos circunferenciais nos membros inferiores apresentam circulação linfática comprometida e alta probabilidade para o desenvolvimento de linfedema.
\end{abstract}

Palavras-chave: Linfedema. Lesões dos Tecidos Moles. Pé. Fáscia. Cintilografia.

\section{REFERENCES}

1. Barret T, Choyke Pl, Kobayshi H. Imaging of the lymphatic system: New horizons. Contrast Med Mol Imaging. 2006;1(6):230-45. doi: 10.1002/ cmmi.116.

2. Executive Committee. The diagnosis and treatment of peripheral lymphedema: 2016 Consensus document of the International Society of Lymphology. Lymphology. 2016;49(4):170-84.

3. Szuba A, Rockson SG. Lymphedema: Classification, diagnosis and therapy. Vasc Med. 1998;3(2):145-
56. doi: $10.1177 / 1358836 \times 9800300209$.

4. Maclellan RA, Greene AK. Lymphedema. Semin Pediatr Surg. 2014;23(4):191-7. doi: 10.1053/j. sempedsurg.2014.07.004.

5. Kerchner K, Fleischer A, Yosipovitch G. Lower extremity lymphedema. J Am Acad Dermatol. 2008;59(2):324-31. doi: 10.1016/j. jaad.2008.04.013.

6. Murdaca G, Cagnati P, Gulli R, Spano F, Puppo F, Boccardo F. Current views on diagnostic approach and treatment of lymphedema. Am J Med. 2012;125(2):134-40. doi: 10.1016/j. 
amjmed.2011.06.032.

7. Swartz MA. The physiology of the lymphatic system. Adv Drug Deliv Rev. 2001;50(1-2):3-20. doi: 10.1016/s0169-409x(01)00150-8.

8. Warren AG, Brorson H, Borud LJ, Slavin SA. Lymphedema - A comprehensive review. Ann Plast Surg. 2007;59:464-472. doi: 10.1097/01. sap.0000257149.42922.7e.

9. Boccardo F, Campisi CC, Molinari L, Dessalvi S, Santi PL, Campisi C. Lymphatic complications in surgery: Possibility of prevention and therapeutic options. Updates Surg. 2012;64(3):211-6. doi: 10.1007/s13304-012-0165-0.

10. Cohen MD. Complete decongestive physical therapy in a patient with secondary lymphedema due to orthopedic trauma and surgery of lower extremity. Phys Ther. 2011;91(11):1618-26. doi: 10.2522/ptj.20100101.

11. Balakrishian C, Webber JD, Prasad JK. Lymphedema of lower extremities following debridement of extensive full skin burns. Burns. 1994;20(4): 365-6. doi: 10.1016/0305-4179(94)90070-1.

12. Godoy ACP, Troitino RO, Godoy MFG, Godoy JMP. Lymph drainage of posttraumatic edema of lower limbs. Case Rep Orthop. 2018;2018:7236372. . doi: 10.1155/2018/7236372.

13. Mowlen $\mathrm{R}$. The treatment of lymphedema. $\mathrm{Br} \mathrm{J}$ Plast Surg. 1948;1(1):48-55. doi: 10.1016/s00071226(48)80008-1.

14. Casley-Smith JR. A case of localized traumatic lymphoedema: Observations concerning the obstruction of initial lymphatics and tissue channels by fibrin, and Menkin's hypothesis. Lymphology. 1983;16(3):143-9.

15. Anand S, Lal H, Dhaon BK. Lymphedema of lower extremity as a complication of local burns. Burns. 1998;24(8):767-9. doi: 10.1016/s03054179(98)00078-3.

16. Mihara $M$, Har $H$, Murai $N$, Todokoro $T$, Lida T, Koshima I. Severe lymphedema caused by repeated self-injury. Lymphology. 2011;44:183-6.

17. Kim BH, Sim YJ, Jeong HJ, Kim GC, Kim DK. Delayed lymphedema after skin lesion. Lymphat Res Biol. 2014;12(1):48-51. doi: 10.1089//rb.2013.0022.

18. Van Zanten MC, Mistry RM, Suami H, Campbell-
Lloyd A, Finkemeyer JP, Piller NB, et al. The lymphatic response to injury with soft-tissue reconstruction in high energy open tibial fractures of the lower extremity. Plast Reconstr Surg. 2017;139(2):483491. doi: 10.1097/PRS.0000000000003024.

19. Mello DF, Assef JC, Solda SC, Helene Jr A. Desenluvamento de tronco e membros: comparação dos resultados da avaliação precoce ou tardia pela cirurgia plástica. Rev. Col. Bras. Cir. 2015;42(3):1438. doi: 10.1590/0100-69912015003003.

20. Mello DF, Demario LA, Solda SC, Helene Jr A. Desenluvamentos fechados - Lesão de MorelLavallée. Rev Bras Cir Plast. 2010;25(2):355-60.

21. Godoy JMP, Andrade M, Azevedo Jr WF, Beltramino RA, et al. IV Latin American consensus on the treatment of lymphedema. J Phebol Lymph. 2011; 4:13-16.

22. Rockson SG. Causes and consequences of lymphatic disease. Ann NY Acad Sci. 2010;1207 Suppl 1:E26. doi: 10.1111/j.1749-6632.2010.05804.x.

23. Dalia RM, Martins GRP, Barbosa R, Lima CF, Siqueira CF. Qualitative and quantitative lymphoscintigraphy in the evaluation of lower limbs lymphedema. Braz. arch. biol. technol. 2005;48(2):159-62. doi: 10.1590/S1516-89132005000700023.

24. Infante JR, Garcia L, Laguna P, Duran C, Rayo $J$, et al. Lymphoscintigraphy for differential diagnosis of peripheral edema: Diagnostic yield of different scintigraphy patterns. Rev Esp Med Nucl Imagen Mol. 2012;31(5):237-42. doi: 10.1016/j. remn.2011.11.011.

25. Macdonald JM, Sims N, Mayrovitz HN. Lymphedema, lipedema, and the open wound The role of compression therapy. Surg Clin North Am. 2003; 83(3):639-58. doi: 10.1016/500396109(02)00201-3.

26. Engeset A. Trauma and lymphatic injury - Letter to the editor. Lymphology. 2002;35(3):130-1.

27. Lorhmann C, Pache G, Felmerer G, Foeldi E, Schafefer O, Langer M. Posttraumatic edema of the lower extremities: Evaluation of the lymphatic vessels with magnetic resonance lymphangiography. J Vasc Surg. 2009;49(2):417-23. doi: 10.1016/j. jvs.2008.08.069.

28. Suga K, Kume N, Matsunga N, Motoyama K, 
Ogasawara N. Assessment of leg edema by dynamic lymphoscintigraphy with intradermal injection of technetium-99m human serum albumin and load produced by standing. Eur J Nucl Med. 2001;28(3):294-303. doi: 10.1007/ s002590000418.

29. Akita S, Mitsukawa N. Comparison of preoperative and postoperative lymphatic function is essential to understand the changes in lymphatic function. Plast Reconst Surg. 2017;140(1):239e-240e. doi: 10.1097/PRS.0000000000003463.

30. Xiong L, Engel H, Gazyakan E, Rahimi M, Hünerbein $M$, Sun J. Current techniques for lymphatic imaging: State of the art and future perspectives. Eur J Surg Oncol. 2014;40(3):270-6. doi: 10.1016/j. ejso.2013.11.027.

31. Silva JH, Perez MDCJ, Barros Jr N, Castiglioni MLV, Novo NF, Miranda Jr F. Doença veno-linfática: Alterações linfocintilográficas nas úlceras venosas. J vasc bras. 2009;8(1):33-42. doi: 10.1590/S167754492009000100006.

32. Kleinhans E, Baumeister RGH, Hahn D, Siuda S,

Received in: 15/02/2021

Accepted for publication: 20/10/2021

Conflict of interest: no.

Funding source: none.
Bull U, Moser E. Evaluation of transport kinetics in lymphoscintigraphy: Follow-up study in patients with transplanted lymphatic vessels. Eur J Nuc Med. 1985;10(7-8):349-52. doi: 10.1007/ BF00251310.

33. Sapienza MT, Endo IS, Ferraro GC, Tavares MGM, Campos Neto GC, Guedes Neto HJ, et al. Critérios semiquantitativos de análise linfocintilográfica em linfedema de membros inferiores. J vasc bras. 2006;5(4):288-94. doi: 10.1590/S167754492006000400008 .

34. Ngo Q, Suami $H$, Koelmeyer L, Mackey $H$, Munot $\mathrm{S}$, Boyages J. Is lymphatic reconstitutuion possible after meshed skin grafting? Lymphology. 2018;51(3):132-5.

35. Amann-Vesti BR, Ruesch C, Gitzelmann G, Koppensteiner R. Microangiopathy of split skin grafts in venous ulcers. Dermatol Surg. 2004;30(3):399402. doi: 10.1111/j.1524-4725.2004.30109.x.

36. Brorson H. Liposuction in arm lymphedema treatment. Scand J Surg. 2003;92(4):287-95. doi: $10.1177 / 145749690309200409$.
Mailing address:

Daniel Francisco Mello

E-mail: mello.plastica@gmail.com 